-

\title{
Contingency Factors Influencing Implementation of Physical Asset Management Practices
}

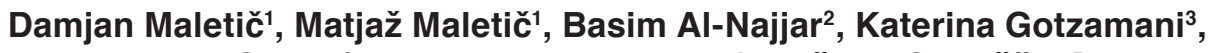 \\ Maria Gianni ${ }^{3}$, T. Bartosz Kalinowski ${ }^{4}$, Boštjan Gomišček ${ }^{5}$ \\ ${ }^{1}$ Faculty of Organizational Sciences, University of Maribor, Slovenia \\ damjan.maletic@fov.uni-mb.si, matjaz.maletic@fov.uni-mb.si \\ 2 School of Engineering, Linnaeus University, Sweden \\ basim.al-najjar@Inu.se \\ ${ }^{3}$ Department of Business Administration, University of Macedonia, Greece \\ kgotza@uom.edu.gr, giannima@uom.edu.gr \\ ${ }^{4}$ Faculty of Management, University of Lodz, Poland \\ tbkalinowski@uni.lodz.pl \\ ${ }^{5}$ Faculty of Business, University of Wollongong in Dubai, UAE \\ BostjanGomiscek@uowdubai.ac.ae
}

Purpose: The purpose of this empirical study is to examine the role of two contingency factors, i.e. uncertainty and competitiveness in relation to physical asset management (PAM) practices as well as to maintenance key performance indicators. The research is based on a premise that PAM, which was defined by risk management practices, performance assessment practices, life cycle management practices, and policy \& strategy practices, has become an indispensable element of strategic thinking of asset owners as well as maintenance and asset managers. The purpose of this study is to advance the understanding of how organizations that face high or low level of uncertainty and competitiveness respond in terms of PAM deployment.

Methodology/Approach: This study employed a data set based on a large-scale survey among organizations in six European countries (i.e. Slovenia, Poland, Greece, Sweden, Turkey and Slovakia). Data were collected from 138 organizations located in the above-mentioned countries to conduct the study.

Findings: The results show that organizations that are faced with high level of uncertainty and competitiveness are more engaged in the deployment of PAM practices. Moreover, results show that when organizations are facing high levels of competitiveness they are using KPIs to a greater extent than organizations under low levels of competitiveness.

Originality/value: From a theoretical perspective, this study contributes to the contingency theory by providing empirical evidence whether a context-dependent approach to PAM is needed. The findings also provide insights for managers on how to respond to the competitive pressure as well as how to customize PAM practices in order to adapt to the changes in dynamic organizational environment.

Keywords: Physical asset management, maintenance, uncertainty, competitiveness, maintenance key performance indicators, empirical study 


\section{Introduction}

In today's increasingly complex interrelated industries, success depends on offering higher customer value or operating with lower costs (Porter, 1985). One important way in which competitive performance could be achieved is through effective management of physical assets (Schuman \& Brent, 2005). In the present business environment, physical asset management (PAM) is becoming a key challenge for business organisations and has acquired more importance as a management function than ever before (Emmanouilidis \& Komonen, 2013). The recent publication of ISO 55000 standards for asset management encouraged the interest on this topic even more. In the context of manufacturing and process industry PAM has been evolving in order to help asset and maintenance managers to exploit full potential of the companies and effectively reach their business goals.

One of the main tasks of PAM is to guarantee that the changing business requirements and physical assets match together in an optimal way, taking into account all life cycle aspects of equipment (Emmanouilidis \& Komonen, 2013). However, there is growing debate over the difference between asset and maintenance management. Many researchers argue that PAM is more profound than maintenance management (Amadi-Echendu et al., 2007). Traditionally, maintenance, with its multifaceted activities, resources, measurement, and management, has been important to manufacturing organizations. However, in recent years, the need to manage different aspects of maintenance more effectively has increased the importance of the role of maintenance in organizations (Simões, Gomes, $\&$ Yasin, 2011). In any industrial practice, the basic effort is to reduce costs and increase profit (Pacaiova, Glatz, \& Kacvinsky, 2012). As outlined by Al-Najjar (2002), the role of maintenance with respect to production is to maintain the quality of all the essential elements that contribute to the production process to keep the product quality and delivery on time at a competitive price.

The main challenge facing operating and production organizations is the necessity to maintain, and often increase, operational effectiveness, revenue and customer satisfaction, while simultaneously reducing capital, operating and support costs (Mitchell, 2002). As such, one should say that PAM could be considered as maintenance management, which has a strategic role in the organization and goes well beyond the responsibility of traditional maintenance management. An important aspect of PAM is to strike the right balance between performance, cost and risk in pursuing the enterprise goals. In other words, it supports managing investments, capacity and production in a more efficient, better quality-assured, safer and more competitive way (Emmanouilidis \& Komonen, 2013). Thus, it is no longer sufficient to consider PAM as traditional asset maintenance, but rather as a holistic approach to the management of assets, taking into account elements such as strategy, risk measurement, safety, environment and human factors (Frolov et al., 2010).

Although there is a great body of literature covering various aspects of PAM (e.g. Emmanouilidis \& Komonen, 2013; Komonen, Kortelainen, \& Räikkönen, 2012; Amadi-Echendu et al., 2007; Schuman \& Brent, 2005; Ratnayake, 2013; Ratnayake \& Markeset, 2012), there is a lack of empirical studies that have explored the PAM practices. As such, PAM as a discipline and business process is yet being at its early stage within the scientific debate and solutions to support its adoption in different industrial contexts are still under definition (Roda \& Macchi, 2016). We aim to fill this research gap by demonstrating the effect of contingency factors (i.e. uncertainty and competitiveness) on PAM practices.

Furthermore, asset performance measurement is essential in order to achieve desired business objectives within the domain of PAM. From industrial and asset life-cycle perspectives, what to measure and what not, is a challenge (Parida, 2016), especially due to dynamic business environment and complex technical assets and systems. However, literature on asset performance measurement has been evolving in scientific research (Attwater et al., 2014). Since there has been no studies that would have explored how organizations respond in competitive environment, with respect to asset performance measurement, this study contributes to the literature by exploring the role of contingency factors on the use of maintenance and asset measures.

The paper is organized as follows. In Section 2, the theoretical background is provided. Section 3 is devoted to presentation of research methods. The research analysis and results are presented in Section 4, followed by the discussion in Section 5 and conclusions in Section 6.

\section{Literature review}

\subsection{Physical asset management}

Before discussing the literature review on the role of PAM in organization, it is necessary to define the maintenance and asset management. The scope of maintenance in a manufacturing environment is illustrated by its various definitions. The British Standards Institute defines maintenance as "A combination of all technical and associated administrative activities required to keep equipment, installations and other physical assets in the desired operating condition or restore them to this condition" (BSI, 1984). Over the time, maintenance has developed across a wider range, and thus maintenance management has been defined.

In European Standards considering maintenance (EN 13306:2010), maintenance management is defined as all activities of the management that determine the mainte- 
nance objectives or priorities, strategies, and responsibilities and implement them by means such as maintenance planning, maintenance control and supervision, and several improvement methods including economical aspects in the organization.

Further, Wireman (1998) has, in his book "Developing Performance Indicators for Managing Maintenance", defined maintenance management as, "The management of all assets owned by a company, based on maximizing the return on investment in the asset". Another approach can be found in Crespo Marquez and Gupta (2006). The authors presented a holistic framework for managing the maintenance function.

They suggest that maintenance management must be aligned with actions at three levels of business activities (i.e. strategic, tactical and operational). More recently, PAM comes to the forefront. It goes well beyond the scope of maintenance management. The PAM deals with the whole life cycle of the asset, from its design to its final disposal. According to Mitchell (2002), asset management is "A comprehensive, fully integrated strategy process and culture directed at gaining greatest lifetime effectiveness, value, profitability and return from production and manufacturing equipment assets". Moreover, European Federation of National Maintenance Societies (EFNMS, 2009) has preferred a simple definition "The optimal life cycle management of physical assets to sustainably achieve the stated business objectives".

In any asset intensive industry, effective management of physical assets is crucial. Changing business environment has increased the strategic importance of PAM in companies that have significant investments in physical assets (Komonen et al., 2012). Without proper management of physical assets serious health, safety, environment, and financial consequences can occur (Ratnayake \& Markeset, 2012). It is widely acknowledged that profitability increases by improving availability and preventing loss of production and loss of human or capital resources (Duijm, Fiévez, Gerbec, Hauptmanns, \& Konstandinidou, 2008).

This means that ineffective asset and maintenance management could be attributable to issues such as lost profit due to missing production during planned and unplanned stoppages, loss of customers, reputation and consequently loss of market share because of maintenance-related factors resulting in delivery delay and poor quality (Al-Najjar, 2007; Maletič, Maletič, Al-Najjar, \& Gomišček, 2014). To improve performance and gain competitive advantage, the PAM process should therefore include activities covering entire life cycle of an asset (Maletič, 2015). In this respect, the life cycle phases are considered as presented in Figure 1.

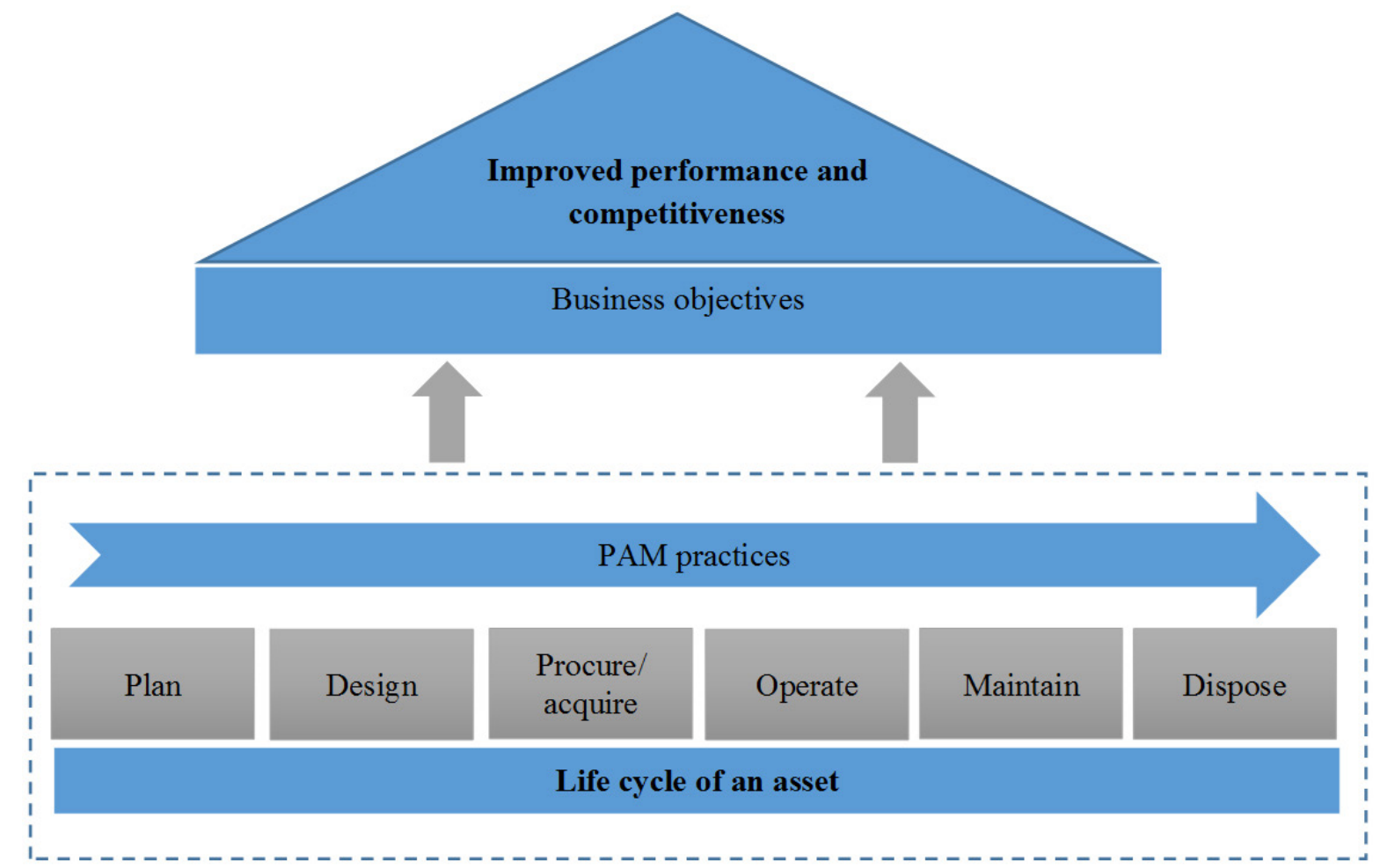

Figure 1: Asset life cycle phases 


\subsection{Asset performance measurement}

From the operation's perspective, a performance measurement can be defined as the process of quantifying the efficiency and effectiveness of an action (Neely, 1994). Like other manufacturing functions, performance measurement is important in managing the maintenance and asset function (Muchiri, Pintelon, Gelders, \& Martin 2011). According to Parida (2016), proactive asset performance management maintains assets at minimum costs at reduced inventory, outsourcing with reduced downtime, risk and reliability improvement.

Furthermore, author argues that asset performance measurement should consider the asset life cycle and whole life value from the owner and operator's perspective to achieve the operational readiness of the assets. It is worth mentioning that with the introduction of ISO 55000 standard, the asset performance measurement has been gaining importance. As such, it can be argued that performance measurement is vital for asset management in terms of balancing the costs, opportunities and risk against the desired performance of assets, to achieve the organizational objectives (ISO 55000, 2014). However, literature (e.g. Attwater et al., 2014) revealed that there is still little research done on performance measurement systems for asset management holistically and systematically.

\subsection{Contingency theory and factors}

Several authors suggests in the literature that organizational practices are formulated in the light of perceived environmental conditions and internal capabilities (Sila, 2007). Contingency theory assumes that organizations attain effectiveness by fitting the characteristics of the organization to contingencies that reflect the situation of the organization (Donaldson, 2001). Different contingency and institutional variables have been identified in the literature as factors that influence the customization of the organizational practices as well as the relationship between these practices and performance implications (e.g. Sila, 2007; Zhang, Linderman, \& Schroeder, 2012).
The stability of the competitive environment in the past decades has been replaced by increasing uncertainty. Product life cycles are becoming shorter, customers are changing their preferences faster, and competition has become increasingly fiercer (Dreyer \& Grønhaug, 2004). Further, competitive environment is also one of the key characteristics of the strategic management discipline that has emphasis on organization's performance (Jansen, Van Den Bosch, \& Volberda, 2006). Accordingly, competitive environments have been associated with intensive pressures for higher efficiency and lower prices (Matusik \& Hill 1998).

\section{Methods}

\subsection{Sample and data collection}

The data used in this study was obtained from a research project conducted by a team of international researchers in the field of maintenance and asset management (Maletič et al., 2016; Maletič, 2015). This research utilizes a questionnaire survey, which corresponds to the primary source as a way of data collection method (Kumar, 2005). The target survey population consisted of international e-mail lists of managers across a wide range of functions. In total, 138 usable responses were collected during the given time window in 2014 and 2105 . The questionnaire was responded by organizations that were located in Slovenia, Poland, Greece, Sweden, Turkey and Slovakia, in portion of $31.9 \%, 34.1 \%, 16.7 \%, 6.5 \%, 5.8 \%$ and $5.1 \%$, respectively. Primarily, the rationale for the selection of the particular countries was based on the sampling strategy to obtain a good spread of countries by geographic, economic, political and social criteria.

In terms of organizational size (following the guidelines of the Statistical Office of the Republic of Slovenia), profile of the organizations is provided in Table 1.

Based on Slovenian Standard Industrial Classification Codes (SIC), Table 2 shows the industry structure of the organisations under investigation. As shown in Table 2,

Table 1: Sample distribution by size of the organizations

\begin{tabular}{|c|c|}
\hline Size & Share (\%) \\
\hline $0-5$ & 12.2 \\
\hline $6-50$ & 17.4 \\
\hline $51-250$ & 31.3 \\
\hline $251-500$ & 21.7 \\
\hline over 500 & 12.2 \\
\hline Data not available & 5.2 \\
\hline Total & 100 \\
\hline
\end{tabular}


most respondents $(39.3 \%)$ indicate that their organizations were active in the 'manufacturing' industry.

\subsection{Measures}

We undertook an intensive review of the literature to identify measures for PAM practices. The instrument developed in this study consists of two major parts. The first part comprises four constructs measuring PAM practices, and the second part comprises two constructs measuring uncertainty and competitiveness. A 5-point Likert scale was used to capture the extent to which organizations are deploying PAM practices as well as to assess the level of uncertainty and competitiveness.

The four constructs for measuring PAM are the following: risk management, performance assessment, life cycle management, and policy \& strategy. Items for measuring these constructs were derived from past studies on PAM (e.g. EFNMS - EAMC, 2012; Emmanouilidis \& Komonen, 2013, Maletič, 2015; Maletič et al., 2016). Items related to uncertainty and competitiveness were developed based on prior empirical studies in the field of quality management (e.g. Zhang et al., 2012; Jansen, Van Den Bosch, \& Volberda, 2006). The list of all items is presented in Appendix A.

Additionally, several key performance indicators (KPIs) were used in this study as well. The KPIs were identified based on maintenance and asset performance measurement literature (e.g. Parida, Kumar, Galar, \& Stenström, 2015; Muchiri et al. 2011; Maletič et al., 2012). A 5-point Likert scale was used to assess how much emphasis is placed on each of the KPIs. A review of the past research on asset performance measurement literature in- dicates that many different KPIs exist for measuring maintenance and asset performance in organizations. Despite the importance of performance measurement within the PAM (Parida, 2016), the aim of this study is not a comprehensive research of asset performance measurement, but rather the investigation of the impact of contingency factors on the use of KPIs in organizations. As such, for the purpose of this study, we built a construct for exploring the use of KPIs in organizations based on few most commonly used KPIs in maintenance and asset management field (Simões, Gomes, \& Yasin, 2016).

\section{Results}

\subsection{Scale validity and reliability}

The scales for PAM practices were subjected to validity and reliability tests. The construct validity was assessed merely using exploratory factor analysis (EFA) based on oblique rotation (Direct Oblimin). The scale reliability was tested by calculating its Cronbach's alpha. Additionally, we performed corrected item-total correlations (CITCs) in order to strengthen validity and reliability results.

The factor loadings and corresponding CITCs are shown in Appendix A. The results show four factors with eigenvalues greater than one, accounting for $66.9 \%$ of the variance (K-M-O statistic 0.937; Bartlett statistic 2819.395; significance 0.000). According to Field (2005), data are suitable for factor analysis (i.e. $\mathrm{K}-\mathrm{M}-\mathrm{O}>0.5$; Bartlett test of sphericity is significant). The first factor shows the variables having a common underlying dimen-

Table 2: Sample distribution by industry type

\begin{tabular}{|c|c|}
\hline Industry (standard industrial classification) & Share (\%) \\
\hline Agriculture, Forestry and Fishing & 1.7 \\
\hline Mining and Quarrying & 39.3 \\
\hline Manufacturing & 2.6 \\
\hline Electricity, Gas, Steam and Air Conditioning Supply & 0.9 \\
\hline Water Supply, Sewerage, Waste Management and Remediation Activities & 6.8 \\
\hline Construction & 16.2 \\
\hline Transportation and Storage & 5.1 \\
\hline Accommodation and Food Service Activities & 0.9 \\
\hline Information and Communication & 3.4 \\
\hline Financial and Insurance Activities & 0.9 \\
\hline Ond Retail Trade, Repair of Motor Vehicles and Motorcycles & 16.2 \\
\hline Total & 100 \\
\hline
\end{tabular}


sion of "risk management". The second factor named "performance assessment", includes the variables relating to measurement and improvement of PAM. The third factor, "life cycle management" captures the common underlying theme of managing entire life cycle of physical assets. The fourth factor is named "policy \& strategy", includes variables related to the organization's activities that exemplify asset management policy and strategy formulation.

\subsection{Descriptive statistics}

The results presented in Table 3 include means, standard deviations, and bivariate correlations for all composite variables in this research. As it can be seen from Table 3 the highest mean value corresponds to the life cycle management (mean 3.72, s.d. 0.81), while the lowest value corresponds to the performance assessment (mean 3.43, s.d. 0.87). Table 3 presents the results of the correlation coefficients. One can see that all correlation coefficients are statistically significant and range from 0.644 to 0.887 $(\mathrm{p}<0.01)$.

\subsection{Difference of means (t-test)}

T-test was used to examine whether a significant difference exists related to PAM practices`implementation between the two groups for each corresponding construct: low level and high level of uncertainty and competitiveness (Table 4). A score of 4 and above was treated as a high, and a score of 3 or below was treated as a low level group.

The results show that there are significant differences between the mean values of the PAM concerning the low and high levels of uncertainty and competitiveness $(\mathrm{t}=$ $-2.014, \mathrm{p}<0.05, \mathrm{t}=-2.109, \mathrm{p}<0.05$, respectively).

\subsection{Contingency factors and key perfor- mance indicators}

The results presented in Table 5 illustrate the descriptive statistics and summary of t-tests results for the KPIs. The independent t-tests were performed within two groups: (1) low and high levels of uncertainty; (2) low and high levels of competitiveness. The results indicate that in the case of uncertainty much emphasis (i.e. mean above 4) is placed on measuring maintenance costs (mean $=4.03$, $\mathrm{SD}=1.113$ ), while the lowest mean value corresponds to the quality rate, particularly in the environment of the low level of uncertainty $($ mean $=3.25, \mathrm{SD}=1.05)$. Regarding the competitiveness results indicate that when organizations are faced with high levels of competitiveness maintenance costs are the most important KPI (mean $=4.10$, $\mathrm{SD}=0.924)$, while less emphasis is put on measuring the

Table 3: Means, standard deviations and correlations

\begin{tabular}{|c|c|c|c|c|c|c|c|}
\hline & Mean & SD & (1) & (2) & (3) & (4) & (5) \\
\hline (1) Physical asset Management & 3.57 & .73 & & & & & \\
\hline (2) Risk Management & 3,60 & .86 & $.887^{* *}$ & & & & \\
\hline (3) Performance assessment & 3.43 & .87 & $.862^{* *}$ & $.659^{* *}$ & & & \\
\hline (4) Life cycle management & 3.72 & .81 & $.862^{* *}$ & $.701^{* *}$ & $.658^{* *}$ & & \\
\hline (5) Policy \& strategy & 3.54 & .82 & $.868^{* *}$ & $.698^{* *}$ & $.663^{* *}$ & $.644^{* *}$ & - \\
\hline
\end{tabular}

** Correlation is significant at the 0.01 level (2-tailed)

Table 4: Summary of the results of the t-test

\begin{tabular}{|c|c|c|c|c|c|}
\hline Construct & Group & Mean & Std. Deviation & Std. Error & $\mathbf{t}$ \\
\hline \multicolumn{6}{|c|}{ Uncertainty } \\
\hline \multirow{2}{*}{$\begin{array}{l}\text { Physical asset } \\
\text { management }\end{array}$} & $\begin{array}{l}\text { Low level } \\
(\mathrm{N}=37)\end{array}$ & 3.36 & 0.737 & 0.121 & \multirow{2}{*}{$-2.014^{*}$} \\
\hline & $\begin{array}{l}\text { High level } \\
(\mathrm{N}=101)\end{array}$ & 3.64 & 0.717 & 0.071 & \\
\hline \multicolumn{6}{|c|}{ Competitiveness } \\
\hline \multirow{2}{*}{$\begin{array}{l}\text { Physical asset } \\
\text { management }\end{array}$} & $\begin{array}{c}\text { Low level } \\
(\mathrm{N}=35)\end{array}$ & 3.35 & 0.782 & 0.132 & \multirow{2}{*}{$-2.109 *$} \\
\hline & $\begin{array}{l}\text { High level } \\
(\mathrm{N}=103)\end{array}$ & 3.64 & 0.700 & 0.069 & \\
\hline
\end{tabular}

$* P<0.05$ 
quality rate $($ mean $=2.91, \mathrm{SD}=1.380)$ and on measuring the number of HSSE $($ mean $=2.91, \mathrm{SD}=1.401)$.

In order to empirically assess whether there are significant differences between means of key performance indicators, we performed several independent t-tests. A p-value of $\leq 0.05$ was considered statistically significant, with effects sizes calculated by a Cohen's d effect size. Cohen (1988, p. 25) hesitantly defined effect sizes as "small, $d=$ 0.2 ," "medium, $\mathrm{d}=0.5$," and "large, $\mathrm{d}=0.8$ ", stating that "there is a certain risk inherent in offering conventional operational definitions for those terms used in power analysis in as diverse field of inquiry as behavioural science”.

An independent samples t-test indicated a significant difference between the low and high levels of uncertainty concerning the maintenance costs $(\mathrm{t}=-2.228, \mathrm{p}<0.05)$. Regarding the competitiveness significant difference was found in the case of overall equipment effectiveness (OEE) $(\mathrm{t}=-2.108, \mathrm{p}<0.05)$, availability of assets $(\mathrm{t}=-2.831, \mathrm{p}<$

Table 5: Differences between low level and high level of contingency in terms of key performance indicators (KPI)

\begin{tabular}{|c|c|c|c|c|c|c|c|}
\hline KPI & Contingency & $\mathrm{N}$ & mean & $\begin{array}{c}\text { Std. } \\
\text { Deviation }\end{array}$ & $\begin{array}{l}\text { Std. } \\
\text { Error }\end{array}$ & $\mathrm{t}$ & $\begin{array}{c}\text { Cohen's } \\
\text { d Effect } \\
\text { Size }\end{array}$ \\
\hline & \multicolumn{6}{|c|}{ Uncertainty } & \\
\hline \multirow{5}{*}{$\begin{array}{l}\text { Overall Equipment } \\
\text { Effectiveness (OEE) }\end{array}$} & Low level & 37 & 3.65 & 0.949 & 0.156 & \multirow{2}{*}{-0.470} & \multirow{2}{*}{0.09} \\
\hline & High level & 80 & 3.75 & 1.142 & 0.128 & & \\
\hline & \multicolumn{6}{|c|}{ Competitiveness } & \\
\hline & Low level & 35 & 3.40 & 1.218 & 0.206 & \multirow{2}{*}{$-2.108 *$} & \multirow{2}{*}{0.40} \\
\hline & High level & 82 & 3.85 & 0.995 & 0.110 & & \\
\hline \multirow{6}{*}{$\begin{array}{c}\text { Availability of as- } \\
\text { sets }\end{array}$} & \multicolumn{6}{|c|}{ Uncertainty } & \\
\hline & Low level & 37 & 3.32 & 1.029 & 0.169 & \multirow{2}{*}{-0.763} & \multirow{2}{*}{0.15} \\
\hline & High level & 80 & 3.50 & 1.396 & 0.156 & & \\
\hline & \multicolumn{6}{|c|}{ Competitiveness } & \\
\hline & Low level & 35 & 2.94 & 1.349 & 0.228 & \multirow{2}{*}{$-2.831 * *$} & \multirow{2}{*}{0.56} \\
\hline & High level & 82 & 3.66 & 1.209 & 0.134 & & \\
\hline \multirow{6}{*}{ Maintenance costs } & \multicolumn{6}{|c|}{ Uncertainty } & \\
\hline & Low level & 36 & 3.53 & 1.108 & 0.185 & \multirow{2}{*}{$-2.228 *$} & \multirow{2}{*}{0.45} \\
\hline & High level & 80 & 4.03 & 1.113 & 0.124 & & \\
\hline & \multicolumn{6}{|c|}{ Competitiveness } & \\
\hline & Low level & 34 & 3.32 & 1.387 & 0.238 & \multirow{2}{*}{$-2.991 * *$} & \multirow{2}{*}{0.66} \\
\hline & High level & 82 & 4.10 & 0.924 & 0.102 & & \\
\hline \multirow{6}{*}{ Quality rate } & \multicolumn{6}{|c|}{ Uncertainty } & \\
\hline & Low level & 36 & 3.25 & 1.105 & 0.184 & \multirow{2}{*}{-0.491} & \multirow{2}{*}{0.11} \\
\hline & High level & 80 & 3.38 & 1.335 & 0.149 & & \\
\hline & \multicolumn{6}{|c|}{ Competitiveness } & \\
\hline & Low level & 35 & 2.91 & 1.380 & 0.233 & \multirow{2}{*}{$-2.411 *$} & \multirow{2}{*}{0.48} \\
\hline & High level & 81 & 3.52 & 1.174 & 0.130 & & \\
\hline \multirow{6}{*}{$\begin{array}{l}\text { Number of HSSE } \\
\text { (Health, safety, secu- } \\
\text { rity and environment) } \\
\text { complaints }\end{array}$} & \multicolumn{6}{|c|}{ Uncertainty } & \\
\hline & Low level & 37 & 3.30 & 1.175 & 0.193 & 1052 & (2) \\
\hline & High level & 79 & 3.58 & 1.438 & 0.162 & -1.002 & 0.21 \\
\hline & & & & titiveness & & & \\
\hline & Low level & 35 & 2.91 & 1.401 & 0.237 & $3114 * *$ & 062 \\
\hline & High level & 81 & 3.74 & 1.273 & 0.141 & -5.114 & 0.02 \\
\hline
\end{tabular}

$N=$ sample size $; M=$ mean $; S D=$ Standard Deviation $; S E=$ Standard Error of the Mean, $* P<0.05, * * P<0.01$ 
$0.01)$, maintenance costs $(\mathrm{t}=2.991, \mathrm{p}<0.01)$, quality rate $(\mathrm{t}=-2.411, \mathrm{p}<0.05)$ and number of $\operatorname{HSSE}(\mathrm{t}=-3.114, \mathrm{p}$ $<0.01)$.

\section{Discussion}

This paper contributes to the literature on contingency theory by developing a better understanding of contingency factors (i.e. uncertainty and competitiveness) regarding the deploying of PAM practices. The results of t-test show that when organizations are faced with high levels of uncertainty they are putting more effort in introducing different PAM practices. Additionally, the results of this study indicate that high levels of competitiveness seem to stimulate the organizations to deploy PAM to a greater extent than organizations that are faced with low levels of competitiveness. As such, these findings contribute to the discussion in the literature concerning the role of contextual factors such as uncertainty (Zhang et al., 2012) and competitiveness (Jansen et al., 2006).

The main theoretical implication of this study is the development of an empirically based and testable framework of PAM practices, which integrates the literature exploring PAM practices (e.g. EFNMS - EAMC, 2012). We used exploratory factor analysis, corrected item-total correlations and reliability estimation using Cronbach's alpha to confirm whether the scales have a factor structure that depicts the theoretical dimensionality of their setting. Our results indicated that PAM comprises of four constructs, namely risk management, performance assessment, life cycle management and policy \& strategy.

Our findings underpin previous studies (e.g. Emmanouilidis \& Komonen, 2013) that have examined the role of PAM practices in industrial sectors. Further, our study supports the view of researchers who argue that holistic views of PAM reflect the general movement in engineering circles to emphasize the importance of PAM and to focus on the bigger picture of life cycle asset assessment, including strategy, risk measurement, safety and environment and human factors (Amadi-Echendu et al., 2007).

Further, this study also contributes to the maintenance and asset performance measurement literature. Recent studies (e.g. Parida et al., 2015) emphasize that the asset managers and owners need to measure and know the relationship between the outputs of asset and maintenance process in terms of its total contribution to the business goal. This means that measurement is fundamental to achieve higher performance, to achieve improvement and business success (Parida, 2016). The findings of this study offer empirical support for the above statements. When facing high levels of competitiveness, the results show that organizations are using KPIs to a greater extent than organizations under low levels of competitiveness. Moreover, KPIs are considered as essential element of asset performance measurement and management, which can support the as- set owners and operators to achieve sustainable asset productivity with a good return on investment (Parida, 2016). In this regard, our study underscores previous studies (e.g. Parida et al., 2015) suggesting that performance assessment ultimately enhances competitive advantage. In contrast to the competitiveness, our study did not reveal any significant dependence between uncertainty and the majority of the KPIs used in this study. It appears that when organization are faced with high level of uncertainty the emphasis on measuring KPIs is not as strong as when organizations are striving to sustain competitive advantage.

From the managerial perspective, the study emphasizes the need to recognize different dimensions of PAM practices. In addition, important information for managers is also to perceive how organizations responded to different environmental conditions (i.e. uncertainty and competitiveness). The increasing turbulent business environment means that organizations are constantly faced with either uncertain and/or competitive environments. From a practical point of view, organizations that want to sustain competitive advantage are recommended to adopt PAM practices. Our study further highlights the need for managers to emphasize the use of KPIs, especially in highly competitive business environments.

\section{Conclusion}

This study contributes to the PAM literature by developing the framework of PAM practices. The empirical analysis evokes a number of important findings. First, our study contributes to the literature by empirically validating the PAM construct. Our study is one of the first to define the construct for measuring PAM. Second, our study presents a step toward uncovering the role of contingency factors in deploying asset management practices as well as the use of KPIs in the field of maintenance and asset management. Building on insights from contingency theory, the findings suggest that contingency perspective is a valuable approach to enrich our understanding of asset management practices implementation as well as asset performance measurement. Third, our study contributes to the literature by suggesting that competitive intensity stimulates organizations to put more effort on PAM. In this regard, PAM can be conceived as an effective approach to gain competitive advantage. Furthermore, based on the results of this study one can argue that competitiveness as a contingency factor can foster the use of KPIs. The latter is especially important to monitor the PAM performance as well as to support the continuous improvement of the PAM system. Identified PAM dimensions alongside with contingency perspective are illustrated in Figure 2.

Although this study contributes to both academia and practice, we acknowledge several limitations that open up avenues for further research. First, future studies should seek additional contingency factors. Therefore, more key 


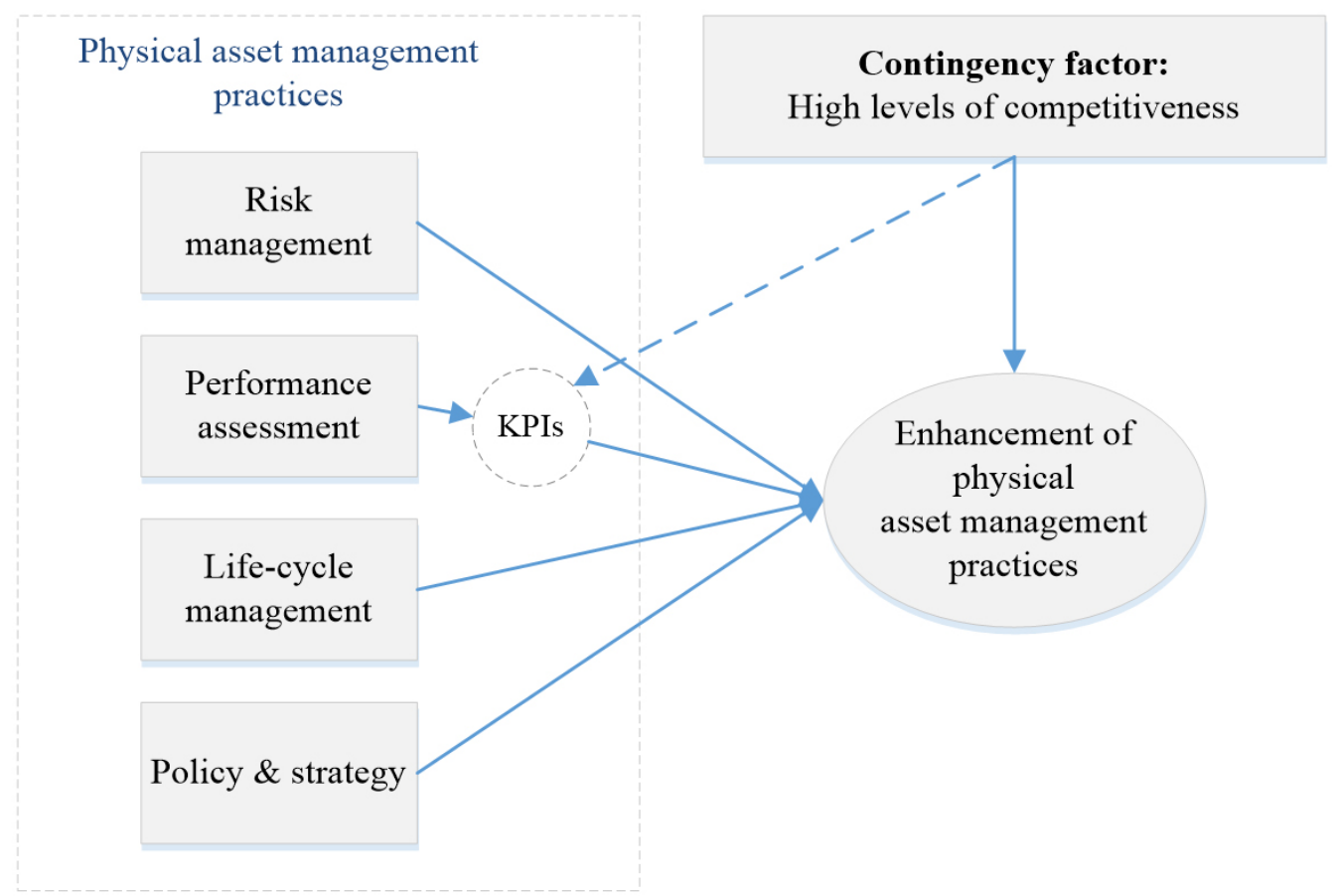

Figure 2. Summary of the study findings

contingency variables need to be identified in the asset management discipline. Second, our construct did not explore the relationship between PAM practices and performance outcome. As such, future studies could focus on the relationship between PAM practices and organizational performance as well. Third, our study did not cover all aspect of asset performance measurement. In this regard, we recommend that future studies should consider more comprehensive set of KPIs and test if different contingency factors encourage their use. Finally, although performance monitoring of assets is well recognized in the literature, performance measurement of the PAM systems is not yet well explored in terms of industrial practice as well as academic research (Attwater et al., 2014). Future studies should therefore focus on this topic as well.

\section{Literature}

Al-Najjar, B. (2002). Company's business and competitiveness enhancement: A model of integrated vibration-based maintenance impact on company's effectiveness. In Proceedings of COMADEM 2002: 15th International Congress on Condition Monitoring and Diagnostic Engineering Management. Paper presented at Condition monitoring and diagnostic engineering management (COMADEM 2002), Sep.2-4, 2002 Birmingham, UK (pp. 238-248).

Al-Najjar, B. (2007). The lack of maintenance and not maintenance which costs: A model to describe and quantify the impact of vibration-based maintenance on company's business. International Journal of Production Economics, 107(1), 260-273, http://dx.doi. org/10.1016/j.ijpe.2006.09.005

Amadi-Echendu, J. E., Willett, R. J., Brown, K. A., Lee , J., Mathew, J., Vyas, N., \& Yang, B.-S. (2007). What is engineering asset management? In Proceedings $2 n d$ World Congress on Engineering Asset Management and the 4th International Conference on Condition Monitoring, pp. 116-129.

Attwater, A., Wang, J. Q., Parlikad, A., \& Russel, P. (2014). Measuring the performance of asset management systems. In Asset Management Conference 2014 (pp. 1-6). IET.

BSI (1984). Glossary of maintenance terms in Terotechnology. British Standard Institution (BSI), London; BS 3811.

Cohen, J. (1988). Statistical power analysis for the behavioral sciences (2nd ed.). Hillsdale, NJ: Lawrence Earlbaum Associates.

Crespo Marquez, A., \& Gupta, J. N. D., (2006). Contemporary maintenance management: process, framework and supporting pillars. Omega, 34(3), 313-326. http:// dx.doi.org/10.1016/j.omega.2004.11.003

Donaldson, L. (2001). The Contingency Theory of Organisation. Sage, Thousand Oaks.

Dreyer, B., \& Grønhaug, K. (2004). Uncertainty, flexibility, and sustained competitive advantage. Journal 
of business research, 57(5), 484-494, http://dx.doi. org/10.1016/S0148-2963(02)00315-6

Duijm, J. N., Fiévez, C., Gerbec, M., Hauptmanns, U., \& Konstandinidou, M. (2008). Management of health, safety and environment in process industry. Safety Science, 46(6), 908-290, http://dx.doi.org/10.1016/j. $\underline{\text { ssci.2007.11.003 }}$

EFNMS (2009). A Definition of Asset Management. Minutes of the meeting. European Federation of National Maintenance Societies. Trondheim. Norway

EFNMS-EAMC (2012). How organizations manage their physical assets in practice, EFNMS Asset Management Survey (EFNMS). Retrieved from http://www.hms-gr. eu/t/files/EAMCSurvey2011ReportFinal02122012.pdf

Emmanouilidis, C., \& Komonen, K. (2013). Physical asset management practices in industry: comparisons between Greece and other EU countries. In V. Prabhu, M. Taisch, D. Kiritsis (Eds.), Advances in production management systems. Sustainable production and service supply chains, IFIP advances in information and communication technology (pp. 509-516). New York, Springer, http://dx.doi.org/10.1007/978-3-642-41263963

EN 13306:2010. (2010). Maintenance Terminology. European Standard. CEN (European Committee for Standardization), Brussels.

Field, A. (2005). Discovering Statistics Using SPSS (Introducing Statistical Methods series). London: Sage Publications Ltd; Second Edition.

Frolov, V., Ma, L., Sun, Y., \& Bandara, W. (2010). Identifying Core Functions of Asset Management. In Amadi-Echendu, J.E.; Brown, K.; Willett, R.; Mathew,J. (Eds.), Definitions, Concepts and Scope of Engineering Asset Management, London \& New York, Springer London, 1sted., Vol. 1, pp. 19-31, http://dx.doi. org/10.1007/978-1-84996-178-3 2

ISO 55000 (2014). Asset management - Overview, principles and terminology

Jansen, J. J. P., Van Den Bosch, F. A. J., \& Volberda, H. W. (2006). Exploratory Innovation, Exploitative Innovation, and Performance: Effects of Organizational Antecedents and Environmental Moderators. Management Science, 52(11), 1661-1674, http://dx.doi. org $/ 10.1287 / \mathrm{mnsc} .1060 .0576$

Komonen, K., Kortelainen, H., \& Räikkönen, M. (2012). Corporate Asset Management for Industrial Companies: An Integrated Business-Driven Approach. In: Van der Lei, T., Herder, P. \& Wijnia, Y. (Eds.), Asset Management: State of the Art in Europe from a Life Cycle Perspective (pp. 47-63). Springer Science, Business Media B. V, http://dx.doi.org/10.1007/978-94007-2724-3 4

Kumar, R. (2005). Research Methodology: A Step-by-Step Guide for Beginners (2nd ed.), London: Sage Publications Ltd.
Maletič, D. (2015). Interaction between Quality Management, Production and Maintenance Performance, $\mathrm{PhD}$ thesis, Faculty of Organizational Sciences, University of Maribor, Kranj.

Maletič, D., Maletič, M., \& Gomišček, B. (2012). The relationship between continuous improvement and maintenance performance. Journal of Quality in Maintenance Engineering, 18(1), 30 - 41, http://dx.doi. org/10.1108/13552511211226175

Maletič, D., Maletič, M., Al-Najjar, B., \& Gomišček, B. (2014). The role of maintenance in improving company's competitiveness and profitability: A case study in a textile company. Journal of Manufacturing Technology Management, 25(4), 441-456, http://dx.doi. org/10.1108/JMTM-04-2013-0033

Maletič, D., Maletič, M., Al-Najjar, B., Gotzamani, K., Gianni, M., Kalinowski, T. B., Pačaiová, H., Nagyová, A. \& Gomišček, B. (2016). The role of contingency factors in physical asset management: An empirical examination. In: Euromaintenance 2016 proceedings: Paper presented at Euromaintenance 2016 (pp. 93-99).

Matusik, S. F., \& Hill, C. W. (1998). The utilization of contingent work, knowledge creation, and competitive advantage. Academy of management review, 23(4), 680-697.

Mitchell, J.S. (2002). Physical Asset Management Handbook, 3rd ed., Clarion Technical Publishers, Houston, TX.

Muchiri, P., Pintelon, L., Gelders, L., \& Martin, H. (2011). Development of maintenance function performance measurement framework and indicators. International Journal of Production Economics, 131(1), 295 - 302, http://dx.doi.org/10.1016/j.ijpe.2010.04.039

Neely, A.D. (1994). Performance Measurement System Design - Third Phase Draft of the Fourth Section of the Performance Measurement System Design Workbook. Centre for Business Performance, Judge Institute of Management Studies, Cambridge, MA.

Pacaiova, H., Glatz, J., \& Kacvinsky, S. (2012). Positive and negative aspect in application of maintenance management philosophy. Journal of Applied Engineering Science, 10(2): 99-105, http://dx.doi.org/:10.5937/ jaes10-2131

Parida, A. (2016). Asset performance measurement and management: Bridging the gap between failure and success. In: Euromaintenance 2016 proceedings: $\mathrm{Pa}$ per presented at Euromaintenance 2016 (pp. 109-116)

Parida, A., Kumar, U., Galar, D., \& Stenström, C. (2015). Performance measurement and management for maintenance: a literature review. Journal of Quality in Maintenance Engineering, 21(1), 2 - 33, http://dx.doi. org/10.1108/JQME-10-2013-0067

Porter, M. (1985). Competitive Advantage: Creating and Sustaining Superior Performance. Free Press, New York. 
Ratnayake, R. M. C. (2013). Sustainable Asset Performance: The Role of PAS $551 \& 2$ and Human Factors. International Journal of Sustainable Engineering, 6(3), no.1, 198-211, http://dx.doi.org/10.1080/193970 38.2012.756074

Ratnayake, R. M. C., \& Markeset, T. (2012). Asset Integrity Management for Sustainable Industrial Operations: Measuring the Performance. International Journal of Sustainable Engineering, 5(2), 145-158, http://dx.doi. org/10.1080/19397038.2011.581391

Roda, I., \& Macchi, M. (2016). Studying the funding principles for integrating Asset Management in Operations: an empirical research in production companies. In: 3rd IFAC Workshop on Advanced Maintenance Engineering, Services and Technology AMEST 2016 - Biarritz, France, 19-21 October 2016. IFAC-PapersOnLine, 49(28), 1-6, http://dx.doi.org/10.1016/j. ifacol.2016.11.001

Schuman, C. A., \& Brent, A. C. (2005). Asset life cycle management: towards improving physical asset performance in the process industry. International Journal of Operations \& Production Management, 25(6), 566 - 579, http://dx.doi.org/10.1108/01443570510599728

Sila, I. (2007). Examining the effects of contextual factors on TQM and performance through the lens of organizational theories: an empirical study. Journal of $\mathrm{Op}$ erations Management, 25(1), 83-109, http://dx.doi. org/10.1016/j.jom.2006.02.003

Simões, J. M., Gomes, C. F., \& Yasin, M. M. (2011). A literature review of maintenance performance measurement: a conceptual framework and directions for future research. Journal of Quality in Maintenance Engineering, 17(2), 116-37, http://dx.doi. org/10.1108/13552511111134565

Simões, J. M., Gomes, C. F., \& Yasin, M. M. (2016). Changing role of maintenance in business organisations: measurement versus strategic orientation. International Journal of Production Research, 54(11), 3329-3346, http://dx.doi.org/10.1080/00207543.2015. 1106611

Wireman, T. (1998). Developing Performance Indicators for Managing Maintenance. New York: Industrial Press.

Zhang, D, Linderman, K., \& Schroeder, R. G. (2012). The moderating role of contextual factors on quality management practices. Journal of Operations Management, 30(1-2), 12-23, http://dx.doi.org/10.1016/j. jom.2011.05.001

Damjan Maletič is an Assistant Professor at the Faculty of Organizational Sciences, University of Maribor. His research activities are mainly devoted to the fields of physical asset management, maintenance and quality management. Currently one main area of his research has focused on studying the relationship between phys- ical asset management practices and organizational performance. He holds a bachelor's degree in Wood Science and Technology (University of Ljubljana) and Organization (University of Maribor).

Matjaž Maletič is an Assistant Professor at the Faculty of Organizational Sciences, University of Maribor. His main research interests focus on understanding the phenomenon of organizational ambidexterity, especially from the perspective of the exploitation-exploration paradigm, corporate sustainability, quality management, and organizational performance. He obtained his PhD degree in Quality Management from the University of Maribor, Faculty of Organizational Sciences.

Basim Al-Najjar is a Professor of Terotechnology at the Linnaeus University, founder/CEO of E-maintenance Sweden AB and Head of the Centre: Cost-effective Industrial Asset Management (CelAM). He obtained his $\mathrm{PhD}$ in Production Management, Lund University, Sweden. His specialties fit also in Industrial Engineering, Maintenance Technology and System Engineering. He is a member of the Scientific board/Swedish Maintenance Society, European Research Network on Strategic Engineering Asset Management, ISEAM (International Society of Engineering Asset management) and IFRIM (International Foundation on research in Maintenance). In a number of international journals, he is on the Editorial board as well as a reviewer for many additional international journals and conferences. He has developed the concept Total Quality Maintenance (TQMain) and three new measuring instruments and recently an additional new DSS called Smart e-Maintenance Decision Support System (Smart eMDSS).

Katerina Gotzamani is a Professor in the Department of Business Administration in the University of Macedonia, Greece. She holds a PhD in Quality Management from the University of Macedonia, Greece. Her previous degrees are M.Sc. in Operations Research \& Information Systems from the London School of Economics and B.Sc. in Mathematics from the Aristotle University of Thessaloniki, Greece. She is teaching courses in Total Quality Management, Supply Chain Management and Operations Management. Her research interests include total quality management, quality management in the public sector, quality management in e-commerce, management systems standards, operations research methodologies integrated in service quality management, logistics and supply chain management. She has participated in a number of conferences and seminars and she has published more than 40 articles. 
Maria Gianni is a PhD candidate in the Department of Business Administration in the University of Macedonia, Greece. She holds a M.Sc. in Management of Production Systems from the Aristotle University of ThessaIoniki, Greece. She received her undergraduate degree in Chemical Engineering from the Aristotle University of Thessaloniki, Greece. Her current research interests include integrated management systems, management systems standards, quality management, environmental management and sustainability.

T. Bartosz Kalinowski is an Assistant Professor at the Faculty of Management at the University of Lodz with over 10 years of experience in teaching and research. His current research interests focus on process maturity and its relation with organisational performance.
Head of Knowbase - Centre for Excellence in Research at the Faculty of Management. Lecturer in the field of quality management, process management and organizational improvement on MBA programs, postgraduate studies, full and part time studies. Experienced project manager responsible for supervising over 20 business, research and educational projects.

Boštjan Gomišček, PhD is a professor at Faculty of Business, University of Wollongong in Dubai, UAE. He is predominantly engaged in the following research fields: quality management, sustainable quality management and maintenance management. He has published several research papers in international journals and presented his research work at numerous national and international conferences. 


\section{APPENDIX A: Measurement scales}

The value in parenthesis for each retained item indicates the standardized factor loadings and CITC.

Risk Management

Respondents were asked to indicate how much emphasis is placed on each of the following activities where 1 means totally disagree and 5 means totally agree.

RM1: We embed risk into all activities which could affect assets performance $(0.947 ; 0.785)$

RM2: We analyse IT-system, business system, human resources, competence, etc. and address risk $(0.799 ; 0.755)$

RM3: We analyse operation, production, quality and logistic process and address risk $(0.792 ; 0.764)$

RM4: We perform risk assessment in order to minimize business losses $(0.767 ; 0.815)$

RM5: Risk management is an integrated part of asset management strategy $(0.756 ; 0.782)$

RM6: We analyse equipment failure causes and effects to address risk $(0.657 ; 0.748)$

Performance Assessment

Respondents were asked to indicate how much emphasis is placed on each of the following activities where 1 means totally disagree and 5 means totally agree.

PA1: We exploit asset history to enhance asset knowledge $(0.848 ; 0.761)$

PA2: We regularly review overall effectiveness of asset management activities $(0.830 ; 0.833)$

PA3: We undertake benchmarking to support asset management activities $(0.813 ; 0.784)$

PA4: We monitor key performance indicators (KPIs) to verify the achievement of organization's asset management goals $(0.812 ; 0.800)$

PA5: We proactively pursue continuous improvement of asset management activities $(0.721 ; 0.745)$

PA6: Company collects and analyses data related to asset management activities $(0.681 ; 0.661)$

PA7: We regularly review overall efficiency of asset management activities $(0.673 ; 0.791)$

PA8: We exploit information systems to support asset management activities (ERP, CMMS, AMS, or similar ones) (0.584; $0.580)$

PA9: We monitor condition of critical assets $(0.567 ; 0.745)$

Life cycle Management

Respondents were asked to indicate how much emphasis is placed on each of the following activities where 1 means totally disagree and 5 means totally agree.

LM1: We continuously modernise our assets in accordance with our renewing/revision plans $(0.874 ; 0.732)$

LM2: We continuously rationalise our assets to reduce production cost $(0.866 ; 0.686)$

LM3: We assure quality of our assets during the whole life cycle phases $(0.582 ; 0.675)$

LM4: We assure execution of maintenance processes within all assets' life cycle phases $(0.581 ; 0.741)$

LM5: We execute disposal of assets in accordance with the asset management plan $(0.573 ; 0.670)$

Policy \& Strategy

Respondents were asked to indicate how much emphasis is placed on each of the following activities where 1 means totally disagree and 5 means totally agree.

PS1: We execute asset management strategy $(0.624 ; 0.653)$

PS2: We undertake analyses of asset management policy to determine future production capacity $(0.468 ; 0.652)$

PS3: We apply asset management policy $(0.822 ; 0.570)$

PS4: We develop asset management objectives $(0.463 ; 0.732)$

The value in parenthesis for each retained item indicates the standardized factor loadings.

Uncertainty

Respondents were asked to indicate their level of agreement with the following statements on a scale from 1 to 5 , where 1 means totally disagree and 5 means totally agree. 
UN1: Demand for our organization's products and services is unstable and difficult to predict $(0.980)$

UN2: Our organization must frequently improve its products and practices to keep up with competitors $(0.802)$

UN3: Products/services quickly become obsolete in our industry $(0.786)$

\section{Competitiveness}

Respondents were asked to indicate their level of agreement with the following statements on a scale from 1 to 5 , where 1 means totally disagree and 5 means totally agree.

CO1: Organization is faced with high competitive pressures in global markets $(0.773)$

CO2: Competition in our local markets is intense (0.766)

CO3: Our local markets are characterized by a strong price competition $(0.761)$ 